of the Republic of Poland also provides for two new external audit processes to be introduced in the coming years (2021-2022): comprehensive assessment focused on internal quality assurance activities, which will not be mandatory and is at the request of the educational institution; mandatory assessment of doctoral students / quality of education in doctoral studies for doctoral students (according to the third cycle / doctoral studies).

The article highlights the procedure for assessing the quality of education, approved by the State Accreditation Commission, which consists of several stages, which are carried out in the prescribed manner.

Comprehensive external audit at the request of the university, focuses on the effectiveness of the internal quality assurance system in all areas in which the university provides education and will be carried out by the Polish Accreditation Commission.

In general, the concept of quality of education in academic terms is understood as the formation of organizational ability to identify and absorb knowledge in the sphere of educational needs and the implementation of this knowledge to create mechanisms to meet the expectations of recipients of educational services. Analysis of the quality of education clearly shows that its recipients have different expectations.

Key words: quality of education, external audit, higher education, university, the Republic of Poland.

Дата надходження статті: 29.102021 p.

Рецензент: доктор педагогічних наук, професор Біницька К. М.

У,ДК 37.07:005.95

DOI https://doi.org/10.37915/pa.vi50.322

Одайник С. Ф.,

orcid.org/0000-0002-5675-0359

\title{
УПРАВЛІННЯ ПРОФЕСІЙНИМ РОЗВИТКОМ ПЕДАГОГІЧНИХ ПРАЦІВНИКІВ: МОТИВАЦІЙНИЙ МЕХАНІЗМ, КРИТЕРІЇ ЕФЕКТИВНОСТІ
}

У статті розглядаються теоретичні і практичні аспекти та облрунтовуеться необхідність застосування мотивацційного механізму управління професійним розвитком педагогічних працівників. Сутність мотиваціийного механізму управління професійним розвитком педагогів автором тлумачиться як сукупність дій об'єктів і суб'єктів управління, спрямованих на перетворення зовнішнього управлінського впливу на внутрішній поштовх мотив - на основі узгодженості інтересів і потреб взаємодіючих сторін.

Визначено, щзо управління професійним розвитком педагогічних працівників на основі мотиваційного механізму передбачає розроблення та застосування суб'єктами управління системи заохочень учителів, засобів стимулювання мотивації та впливу на когнітивну і діяльнісну сферу професійного розвитку вчителя.

Визначено критерії ефективності управління професійним розвитком педагогічних працівників на основі мотиваційного механізму, а саме: нормативно-адміністративний, Фінансово-економічний, соціально-психологічний. Нормативно-адміністративний критерій відображає, наскільки суб'єкти управління орієнтуються на професійні інтереси, потреби, запити педагогів і діють через правові норми. Фінансово-економічний критерій свідчть про фінансову спроможність суб'єкта управління здійснювати матеріальне стимулювання

*C) Одайник C. $\Phi$.

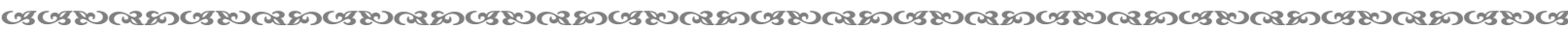
188 
мотивації педагогічних працівників до професійного розвитку $i$ діють з урахуванням результатів професійного зростання вчителів та показників діяльності закладу освіти. Соціально-психологічний критерій ьрунтується на використанні суб'єктали управління моральних стилулів до праці і діють в інтересах професійного розвитку кожного педагога та підвищення якості діяльності закладу освіти. Окреслено низку проблем, які потребують вирішення з метою ефективного управління професійним розвитком педагогічних працівників.

Ключові слова: засоби управлінського впливу; мотивація; мотиваційний механізм управління; професійний розвиток педагогічних праціівників.

Постановка проблеми. Проблема професійного розвитку педагогічних працівників з огляду на підготовку до впровадження Державного стандарту базової освіти Нової української школи (НУШ) є більш, ніж актуальною. Адже, на відміну від учителів початкової школи, які наразі успішно оволодівають сучасним організаційнометодичним інструментарієм, учителям-предметникам належить найближчим часом засвоїти засади Концепції НУШ та забезпечити впровадження в повному обсязі змісту і методів НУШ у 5-9 класах. Оскільки учасниками інноваційного всеукраїнського проєкту, у рамках якого передбачена підготовка вчителів до експериментального навчання за новим стандартом, визначено обмежену кількість закладів загальної середньої освіти [11], пріоритетним завданням керівників пілотних та інших шкіл є посилення мотивації педагогічних працівників до професійного розвитку.

Аналіз досліджень. Теоретичні і методичні засади управління професійним розвитком педагогічних працівників розгдядади С. Мірошник, О. Отич, А. Пуховська, Т. Сорочан, М. Хоржевська. Особливості управління професійним розвитком учителів викладено у працях О. Галуса, Л. Даниленко, Г. Десятова, Г. Ельникової, Л. Калініної, О. Мармази, В. Маслова, Є. Чернишової; підходи до організації означеного процесу (андрогогічний, компетентнісний, акмелологічний, інтегрований) охарактеризовано О. Вознюк, Є. Голобородько, Г. Даниловою, А. Ніколенко, Н. Протасовою, В. Пуцовим; засоби управлінської підтримки досліджено Л. Аитвинюк, О. Стадник, О. Темченко.

У сучасних наукових працях акцентується необхідність модернізації системи управління професійним розвитком педагогічних працівників, оскільки, за визначенням П. Мартинець, у силу змін соціадьно-освітніх потреб професійні завдання стають усе більш комплексними, що вимагає від педагогів зростаючого рівня професіоналізму [7]. Натомість у педагогічному середовищі спостерігається зниження мотивації вчителів до випереджаючого професійного вдосконалення, що негативно позначається на їхній готовності виконувати складні професійні завдання, пов'язанні з інноваційними змінами в освіті. Це вказуе на необхідність здійснення управдіння мотивацією професійного розвитку педагога.

У теорії і практиці управління професійним розвитком педагогічних працівників більше уваги приділено питанням модернізації моделі, структури, організаційних форм означеної системи; натомість недостатньо приділено увагу мотивації вчителів до професійного розвитку; потребують уточнення критерії ефективності управлінської діяльності, спрямованої на вироблення в педагогів стійкої мотивації до професійного зростання в умовах інноваційних змін.

Метою статті є обгрунтування теоретичних засад та практичних аспектів використання мотиваційного механізму управління професійним розвитком педагогічних працівників; визначення критеріїв ефективності означеного процесу.

Виклад основного матеріалу. Реалізації державної політики у сфері загальної середньої освіти на основі Концепції Нової української школи [8] визначила проведення докорінної та системної освітньої реформи за різними напрямами; зокрема, 
передбачається підвищення рівня оплати праці педагогів. Проте, у новому контексті «мотивація» розглядається не як чинник матеріального заохочення, стимулювання, підтримки, а як ознака готовності вчителя до інноваційних змін у професійній діяльності. А, оскільки педагог як суб'єкт інноваційної діяльності, може запропонувати нові освітні ідеї, педагогічні та управлінські технології [9], що є особливо актуальним для реалізації Концепції Нової української школи, управління професійним розвитком має здійснюватися передусім через мотивацію об'єктів професійного розвитку, якими виступають педагоги.

Зауважимо, що існуе багато точок зору щодо трактування сутності поняття «мотивація». Зокрема, Р.Дафт тлумачить мотивацію як стан людини, що визначає ступінь активності та спрямованості їі дій в конкретній діяльності [2, с. 48]. У свою чергу О. Виханський вважає мотивацію спонукальним чинником активності особистості та спрямованості іiі діядьності [1, с. 243]. Натомість, за визначенням О. Сидоренко, мотивація зрештою і є процесом спонукання себе власне та інших до діяльності, спрямованої на досягнення як особистих цілей, так і мети організації [13, с. 112]. Нам імпонує визначення цього терміна С. Занюком, який сутність мотивації як сукупності внутрішніх і зовнішніх факторів пов'язуе не лише зі спонуканням людини до діяльності, але і з визначенням меж і форм діяльності, які, за умови спрямованості, дають змогу досягнути певної мети [4, с. 174].

У дослідженнях 3 теорії управління персоналом А. Колот вживає термін «мотивація трудової діядьності», розгдядаючи його сутність 3 позиції мотивації працівника до праці через трудову зайнятість, оволодіння засобами виробництва, підготовку до трудового процесу, розвиток конкурентоспроможності [5, с. 39].

У теорії освітнього менеджменту мотивація праці педагогічного колективу розгдядається як одна 3 найваждивіших управдінських функцій, що передбачає заохочення вчителів до діяльності для досягнення цілей організації через задоволення їх власних потреб. Уміння мотивувати персонал - складова управлінської компетентності керівника закладу освіти; завдання менеджера полягає в тому, щоб нейтралізувати властиві людям індивідуальні негативні особливості, розробити систему оцінювання результатів діяльності та визначити стимули, які сприятимуть подадьшому професійному зростанню працівників, виявленню талантів, створенню сприятливого мікроклімату в колективі, стимулюватимуть персонад до взаємодії [12].

Ураховуючи, що педагогічні працівники виступають певними суб'єктами управління, адже їх професійний розвиток - це не лише формальний досвід, який отримується шияхом наставництва, відвідування професійних семінарів, майстерень тощо, а також містить неформальний досвід - самоосвіта, читання професійної літератури, перегляд педагогічних передач, онлайн курси тощо [9], механізм управління професійним розвитком педагогічних працівників як складова частина системи управління, що забезпечує дієвий вплив на фактори, стан яких обумовлює результат діяльності об'єкту управління [6], має носити мотиваційний характер. Це відображається, насамперед, на активізації внутрішніх ресурсів особистості вчителя, спонуканні його до професійної творчості та мобільності, кар'єрного зростання, кінцевою метою чого $є$ становлення стійких особистісних і професійних мотивів, здатних забезпечити формування готовності до змін у педагогічній діядьності. Таким чином мотиваційний механізм управдіння професійним розвитком педагогів розглядаємо як сукупність дій об'єктів і суб'єктів управління, спрямованих на перетворення зовнішнього управлінського впливу на внутрішній поштовх - мотив на основі узгодженості інтересів і потреб взаємодіючих сторін. 
Застосування мотиваційного механізму управління професійним розвитком педагогічних працівників потребуе добору ефективних управлінських засобів, серед яких виокремлюємо передусім стимулювання мотиваційної сфери особистості вчителя, що передбачає певний алгоритм управлінських дій, а саме:

- аналіз нормативно-правових документів, що регулюють діяльність закладу освіти (Колективний договір, Статут, Правила внутрішнього розпорядку, Положення про стимулювання та заохочення працівників, Положення про виплату щорічної грошової винагороди, Подоження про преміювання працівників; розпорядчі документи - накази);

- вивчення особистісних і професійних інтересів, потреб, запитів кожного педагога;

- аналіз умов праці педагогічних працівників (наявність кабінету, облаштування робочого місця, рівень заробітної плати, виплати доплат і надбавок і т. ін.);

- аналіз фактів морального і матеріального заохочення працівників;

- аналіз участі вчителів у проєктній діяльності.

Здійснення комплексного аналізу дасть змогу керівникові закдаду освіти, поперше, визначити стимули мотивації педагогів до професійного розвитку не тільки за змістом, а й за глибиною впливу на творчу активність учителя, адже наявність і дія основних потреб дюдини є постійними й об'єктивними [6]. Оскільки стимуди можуть посилювати або послаблювати силу мотиву, $\lambda$. Декерс відокремлено види стимулювання, що впливають на посилення мотивів, а саме: схвалення, моральне заохочення, матеріальне заохочення, змагання, присутність інших людей, успіх, соціально-психологічний кдімат, суспільна увага, привабливість об'єкта потреби, привабливість змісту діяльності, наявність перспективи, конкретної цілі, прогноз та активність дюдини, функційні стани [3].

По-друге, чим конкретніше визначений стимул, тим ефективнішим буде управлінський вплив на забезпечення можливості реалізації потреб учителя задля посилення його мотивації. Зокрема, для одних такими стимулами слугують зміст педагогічної діяльності, його суспільна користь, для інших - преміювання, високий заробіток, для третіх - просування службовими сходинками, професійна кар'єра, для четвертих - потреба у творчості й пов'язана з нею звичка постійно підвищувати свою педагогічну майстерність [6]. Проте, необхідно використовувати весь комплекс видів стимулювання мотивації до професійного розвитку, орієнтуючись на освітні запити педагогів, оскільки це спонукатиме їх до професійного вдосконалення без прямого управлінського впливу, шляхом активізації внутрішніх рушійних сил.

Управління професійним розвитком педагогічних працівників на основі мотиваційного механізму передбачає розроблення та застосування системи заохочень учителів. Визнання керівництвом закладу освіти важдивості праці педагога має бути передусім обгрунтованим з огляду на якість виконання ним функціональних обов' язків, одне із яких - системне підвищення професійного і загальнокультурного рівнів, удосконалення педагогічної майстерності [10]. Система заохочень має бути схвалена кожним членом педагогічного колективу, оскільки кожен має право на відзначення успіхів у своїй професійній діяльності і справедливе та об'єктивне оцінювання своєї професійної діяльності [там само]. Тому необхідно враховувати, що найбільш мотивуючим є заохочення за таку роботу, яка не просто виконана сумлінно, а яка сприяла реалізації цілей професійного розвитку педагога та меті розвитку закладу освіти. Такий підхід дасть змогу встановити чіткий зв'язок між досягненням мети освітньої діяльності закладу освіти і цілями, які формулює педагог, розробляючи програму власного професійного розвитку.

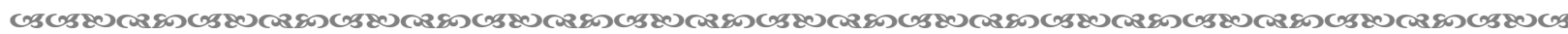


Отже, стимулювання мотивації та система заохочень як засоби мотиваційного механізму управління професійним розвитком педагогічних працівників, з одного боку, забезпечують дослідження керівником закладу освіти інтересів, потреб і запитів учителів та використання отриманої інформації в організації освітньої діяльності, а, з іншого - сприяе усвідомленню педагогами власних особистісних і професійно важдивих якостей, необхідних для вироблення готовності до змін у педагогічній діяльності. Окрім того, стимулювання мотивації є складовою мотиваційного процесу, виявом зовнішньої мотивації, яку здійснюе щодо персоналу адміністрація організації [5, с. 30], а система заохочень сприяє встановленню зв'язку між результатами професійного розвитку педагога й якістю освітньої діяльності закладу освіти.

Щоб посилити мотивацію вчителів до професійного розвитку, окрім стимудювання та заохочення необхідно застосовувати засоби впливу на когнітивну та діяльнісну сферу професійного розвитку вчителя: когнітивна сфера сприяє формуванню широкого спектру сучасних теоретичних знань, професійних компетентностей, діяльнісна - оволодінню технодогіями професійної взаємодії. При цьому важдиво забезпечувати узгодженість інтересів взаємодіючих сторін, що досягається реалізацією суб'єктами управління прав учителів на академічну свободу [10], та однієї із цілей Концепції Нової української шкоди - підготовки висококваліфікованих учителів, з високим рівнем володіння теорією та практикою проєктування інноваційного освітнього середовища [8]. Тому, оскільки професійний розвиток, за визначенням $\Lambda$. Пуховської, здійснюеться на основі різних форм і способів організації [12], керівнику закладу освіти необхідно забезпечувати оптимальний вибір засобів управдіння, які б поєднувади стимулювання мотивації педагогів і водночас підтримували їх прагнення досягати професійних вершин. Для цієї групи засобів є характерним:

- створення ситуації здорової конкуренції, що породжуе мотив до позиціонування накопиченого власного професійного досвіду та сприйняття досвіду колег, унаслідок чого конкурентна поведінка набуває форми співдружності педагогів;

- надання педагогам мождивостей експериментувати, під час чого відбувається рефлексія здобутої професійної практики та зміцнюеться мотив і формується намір оволодіти більш досконалою базою знань, набути нового досвіду педагогічної діяльності;

- залучення педагогів до активного осмислення нових педагогічних теорій, за результатами чого виникає мотив учинити спробу спроєктувати власну модель професійної діяльності для практичного відтворення якої і необхідно розвинути професійні компетентності щодо педагогічної діяльності в умовах інноваційних змін.

Таким чином, професійний розвиток педагогічних працівників є об'єктом управлінської діяльності, яка спрямовується на забезпечення сприятливих умов особистісного і професійного зростання вчителів на основі системного дослідження їхніх освітніх інтересів, потреб, запитів і формування мотивації до змін у педагогічній діяльності згідно із суспільним замовленням.

Нами визначено критерії ефективності управління професійним розвитком педагогічних працівників із застосуванням мотиваційного механізму, а саме: нормативно-адміністративний, фінансово-економічний, соціально-психологічний.

Нормативно-адміністративний критерій відображає, наскільки суб'єкти управління орієнтуються на професійні інтереси, потреби, запити педагогів і діють через правові норми і акти, інструкції, положення, накази та розпорядження. Фінансово-економічний критерій свідчить про фінансову спроможність суб'єкта управління здійснювати матеріальне стимулювання мотивації педагогічних працівників до професійного розвитку, матеріальне заохочення педагогів (заробітна плата, премії 
та інші винагороди) і діють з урахуванням результатів професійного зростання вчителів та показників освітньої діяльності закдаду освіти. Соціально-психологічний критерій грунтується на використанні суб'єктами управління моральних стимулів до праці і діють в інтересах професійного розвитку кожного педагога та підвищення якості освітньої діяльності закладу освіти через вияв поваги до колег; сприяння розвитку їх кар'єри, професійної творчості та майстерності; врахування погдядів та ініціатив учителів, залучення їх до розроблення й ухвалення управлінських рішень.

Висновки. Отже, професійний розвиток педагогічних працівників як об'єкт управлінської діяльності передбачає застосування суб'єктами управдіння мотиваційного механізму, що дає змогу посилювати мотивацію вчителів до засвоєння нових професійних знань, овододіння компетентностями, необхідними для роботи в умовах інноваційних змін. Оптимізація мотивації забезпечується через використання засобів упливу на когнітивну та діяльнісну сферу професійного розвитку вчителя, стимулювання та заохочення працівників. Критеріями ефективності управління професійним розвитком педагогічних працівників на основі мотиваційного механізму є такі: нормативно-адміністративний, фінансово-економічний, соціальнопсихологічний.

Перспективи подальших розвідок будуть спрямовані на розроблення методичних рекомендацій для керівників закладів освіти щодо напрямів оптимізації професійного розвитку педагогічних працівників.

\section{Список використаних джерел:}

1. Виханский О. С., Наумов А. И. Менеджмент: учебн. для вузов. [3-е изд.]. Москва: Гардарики, 2001. 528 c.

2. Дафт Р. А. Менеджмент / пер. с англ. В. Вольского; под общ. ред. Ю. Н. Каптуревского. [2-е изд. ]. Санкт-Петербург: Питер, 2001. 832 с.

3. Декерс А. Мотивация: теория и практика. Расширенный курс. Москва: Гросс-Медиа, 2007. $637 \mathrm{c}$.

4. Занюк С. С. Психология мотивации: теория и практика мотивирования. Мотивационный тренинг. Киев: Эльга-Н: Ника-Центр, 2001. 352 с.

5. Колот А. М. Мотивація, стимулювання й оцінка персоналу: навч. посіб. Київ: КНЕУ, 1998. $224 \mathrm{c}$.

6. Малицький А. А. Організаційно-економічний механізм управління підприємством: сутність та структура. URL: http://intkonf.org

7. Мартинець $\lambda$. А. Особливості управління професійним розвитком учителів. Науковий часопис НПУ імені М. П. Арагоманова. Серія 16: Творча особистість учителя: проблеми теорії і практики. 2016. Вип. 27. С. 19-24.

8. Нова українська школа. Концептуальні засади реформування середньої школи / Міністерство освіти і науки України; [упоряд. А. Гриневич та ін.; заг. ред. М. Грищенко]. Київ, 2016. 35 c. URL: https://goo.su/9cU8

9. Пахомова М.В. Професійний розвиток педагогічних працівників як складова людського розвитку. Професійний розвиток та управління людськими ресурсами в системі післядипломної педагогічної освіти в контексті трансформації освіти України: зб. матеріалів Всеукраїнської наук.-практ. конф., Київ, 28 жовтня 2016 р. / за заг. ред. В. В. Олійника. Київ: УМО НАПН України, 2016. С. 128-133.

10. Про освіту: Закон України від 05.09.2017 p. № 2145-VIII. URL: https://goo.su/9cUi

11. Про реалізацію інноваційного освітнього проєкту всеукраїнського рівня за темою «Розроблення і впровадження навчально-методичного забезпечення для закладів загальної середньої освіти в умовах реалізації Державного стандарту базової середньої освіти»: наказ Міністерства освіти і науки України від 02.04.2021 p. № 406. URL: https://goo.su/9aBu 
12. Пуховська $\Lambda$. Теоретичні засади професійного розвитку педагогів: рух до концептуальної карти. Порівняльна професійна педагогіка: наук. журнал / голов. ред. Н. М. Бідюк. Київ; Хмельницький: ХНУ, 2011. Вип. 1. С. 97-106. URL: https://goo.su/9ABv

13. Сидоренко Е. В. Мотивационный тренинг. Санкт-Петербург: Речь, 2001. 246 с.

\section{References:}

1. Vikhanskii, O. S., \& Naumov, A. I. (2001). Menedzhment [Management]. Moskva: Gardariki [in Russian].

2. Daft, R. L. (2001). Menedzhment [Management]. (V. Volskoho, Trans.). Sankt-Peterburg: Piter [in Russian].

3. Dekers, L. (2007). Motivatciia: teoriia i praktika. Rasshirennyi kurs [Motivation: theory and practice. Advanced course]. Moskva: Gross-Media [in Russian].

4. Zaniuk, S. S. (2001). Psikhologiia motivatcii: teoriia i praktika motivirovaniia. Motivatcionnyi trening [Psychology of motivation: theory and practice of motivation. Motivational training]. Kiev: Elga-N: Nika-Tcentr [in Russian].

5. Kolot, A. M. (1998). Motyvatsiia, stymuliuvannia y otsinka personalu [Motivation, encouragement and evaluation of staff]. Kyiv: KNEU [in Ukrainian].

6. Malytskyi, A. A. (2021). Orhanizatsiino-ekonomichnyi mekhanizm upravlinnia pidpryiemstvom: sutnist ta struktura [Organizational and economical mechanism of an enterprise management: meaning and structure]. Retrieved from http://intkonf.org [in Ukrainian].

7. Martynets, L. A. (2016). Osoblyvosti upravlinnia profesiinym rozvytkom uchyteliv [Teachers professional development management specificity]. Naukovyi chasopys NPU imeni M. P. Drahomanova. Seriia 16: Tvorcha osobystist uchytelia: problemy teorii i praktyky, 27, 19-24 [in Ukrainian].

8. Ministerstvo osvity i nauky Ukrainy. (2016). Nova ukrainska shkola. Kontseptualni zasady reformuvannia serednoi shkoly [New Ukrainian school. Conceptual principles of secondary school reform]. Kyiv. Retrieved from https://goo.su/9cU8 [in Ukrainian].

9. Pakhomova, M. V. (2016). Profesiinyi rozvytok pedahohichnykh pratsivnykiv yak skladova liudskoho rozvytku [Professional development of teachers as a component of human development], Profesiinyi rozvytok ta upravlinnia liudskymy resursamy v systemi pisliadyplomnoi pedahohichnoi osvity $v$ konteksti transformatsii osvity Ukrainy, zb. materialiv Vseukrainskoi nauk.prakt. konf. [Professional development and human resources management in the system of postgraduate pedagogical education in the context of the transformation of education in Ukraine, Proceedings of the All-Ukrainian Scientific and Practical Conference]. Kyiv: UMO NAPN Ukrainy [in Ukrainian].

10. Law of Ukraine About Education dated September 5, 2017, No. 2145-VIII. Retrieved from https://goo.su/9cUi [in Ukrainian].

11. About the implementation of an innovative educational project at the national level on "Development and implementation of educational and methodological support for general secondary education in the implementation of the State Standard of Basic Secondary Education", Order of the Ministry of Education and Science of Ukraine dated April 2, 2021, No. 406. Retrieved from https://goo.su/9aBu [in Ukrainian].

12. Pukhovska, L. (2011). Teoretychni zasady profesiinoho rozvytku pedahohiv: rukh do kontseptualnoi karty [Theoretical principles of professional development of teachers: movement to the conceptual map]. Porivnialna profesiina pedahohika, 1, 97-106. Retrieved from https://goo.su/9ABv [in Ukrainian].

13. Sydorenko, E. V. (2001). Motyvatsyonnyiy trening [Motivational training]. Sankt-Peterburh: Rech [in Russian]. 


\section{MANAGEMENT OF PROFESSIONAL DEVELOPMENT OF PEDAGOGICAL WORKERS: MOTIVATIONAL MECHANISM, CRITERIA OF EFFICIENCY}

The article considers the theoretical and practical aspects, and the necessity of application of the motivational mechanism of management of professional development of pedagogical workers. The essence of the motivational mechanism for managing the professional development of teachers is interpreted by the author as a set of actions of objects and subjects of management aimed at transforming external management influence into internal impulse - motive -based on the interests and needs of interacting parties.

It is determined that the management of professional development of teachers on the basis of the motivational mechanism involves the development and application by management of a system of teacher incentives, means to stimulate motivation and influence upon the cognitive and activity sphere of professional development of teachers.

The criteria of efficiency of management of professional development of pedagogical workers on the basis of the motivational mechanism are defined, namely: normative-administrative, financialeconomic, social-psychological. The normative-administrative criterion reflects the extent to which the subjects of management are guided by the professional interests, needs, requests of teachers and act through legal norms. The financial and economic criterion indicates the financial capacity of management to provide material incentives for teachers to professional development and act taking into account the results of professional growth of teachers and educational performance. Sociopsychological criterion is based on the use of management subjects of moral incentives to work and act in the interests of professional development of each teacher and improve the quality of activities of the educational institution. A number of problems that need to be solved in order to effectively manage the professional development of teachers are outlined.

Key words: professional development of pedagogical workers, motivation, motivational mechanism of management, means of managerial influence.

Дата надходження статті: 28.102021 p.

Рецензент: доктор педагогічних наук, професор, член-кореспондент НАПН України Голобородько Є. П. 